\title{
How to distinguish innovative suppliers? Identifying innovative suppliers as new task for purchasing
}

\author{
Dr. Holger Schiele \\ University of Hanover and h\&z business consulting, Munich / Düsseldorf \\ Universität Hannover, Abteilung Unternehmensführung und Organisation, Königsworther Platz 1, \\ D-30167 Hannover / Germany \\ holger.schiele@iup.uni-hannover.de
}

\begin{abstract}
For companies operating under unfavourable macroeconomic conditions, such as high wage / high tax countries in central Europe, innovation has become a central theme to survive. If there is one thing that has changed in innovation management during the last decade, it is the growing reliance on external sources of technology. As a consequence, a new task for purchasing arises, as firms need an understanding of which suppliers actually do have high potential contributing to the innovativeness of the firm and which do not. This paper focuses on the conceptual basis and derive propositions on the nature of innovative suppliers: specialised, technically competent, export-oriented firms, located in the proximity of the buyer, being embedded in a trusted and intensive relationship are identified as having a higher probability to be the core innovative suppliers. These criteria can serve to refine strategic sourcing decision and improve communication between engineering and purchasing professionals.
\end{abstract}

\section{Keywords}

Innovation, new product development, systems of innovation approach, purchasing, supplier selection, strategic sourcing 


\section{Innovation and purchasing: Selecting innovative suppliers}

In their introduction to a special journal edition on new product development (NPD) Wind and Mahajan state, with some underlying resignation: "Unfortunately, despite marketing, operations, research and development $(R \& D)$, and business strategy disciplines' increased attention to NPD [...] the new product success rate has improved minimally." (Wind, Mahajan 1997, p. 1) Interestingly, purchasing is not mentioned. Could it pave the way out of the dilemma of too slow an increase in innovative output? Purchasing may be a neglected function as far as contributing to a firm's innovativeness and new product development are concerned. One reason: during the 1990ies a fundamental change seems to have occurred in the way innovations are generated. While at the beginning of the decade only one fifth of the most technology-intensive companies were heavily relying on external sources of technology, their share had increased to $85 \%$ in the new millennium (Roberts 2001). Innovation increasingly is not anything anymore that happens in the isolated laboratory of a firm, but involves the supply chain including the firm's suppliers. This is particularly striking if one follows a wider notion of innovation, not necessarily as a world innovation, but as being something new to the firm, regardless of being new to the competitors. It comes as no surprise that a major recent benchmarking study identified a particular commitment to innovation by purchasing as a key feature distinguishing successful firms from those underperforming their industry rivals (Goffre et al. 2005). Still, there is a "dearth of research" into innovation generation in buyer-seller relationships (Roy et al. 2003), let alone for example into purchasing's role in fostering such innovative collaborations (Chen et al. 2004).

To help fill this gap, this paper is going to briefly establish the theoretical link between purchasing and innovation and than focus on one of the core activities of purchasing: supplier selection, more precisely on the selection of innovative suppliers. To understand the characteristics of innovative suppliers a brief literature review will be followed by the derivation of characteristics typical to innovative suppliers. On this basis a shortlist amending the traditional cost focussed supplier evaluation could be developed. Literature, so far, is not providing a comprehensive tool or a set of criteria that can be used in managerial sourcing decisions to filter out innovative suppliers. The purpose of this paper is to provide propositions on such criteria. They could also serve as a basis for empirical verification and amend the current stage of research by stressing more a purchasing related access.

\section{Theoretical background: Innovations in a system}

Håkansson and Eriksson (1993) establish the link between purchasing and innovation via the idea of networks. According to this view, ideas are developed in close exchange with a series of network partners, resulting in the network members' power of innovation becoming determined by the activities of their counterparts. A theoretical approximation to innovation, exploring the concept of innovation as an inter-organisational feedback process, is the "systems of innovation" approach in a broader sense (Edquist 1997; Freeman, Soete 1997; Håkansson 1989; Porter 1990). A common ground within such approaches is the assumption that "...firms almost never innovate in isolation. In the pursuit of innovation they interact with other organizations to gain, develop, and exchange various kinds of knowledge, information, and other resources. [...] therefore it does not make sense to regard innovating firms as isolated, individual decision-making units." (Edquist 1997, p. 1 f.). The idea of innovation being dependent on an entire network has found growing acceptance (e.g. Christensen 1996; Croom 2001; Veludo et al. 2004).

Based on the systemic understanding of innovations, an important distinction can be made: who is innovating? Traditionally, innovation has been considered the product of a single person or an individual company. However, on the basis of an extensive historical research, Freeman and Soete argue in favour of an increasing role played by so called "network-innovations", as opposed to "inventor-innovations" and "laboratory-innovations" (Freeman, Soete 1997; Gammage, Schiele 2000; Schiele 2003). A network-innovation occurs when different actors from different companies with distinct knowledge bases combine their skills, thus improving an existing product or process or even creating a new one. This type of process is explored in the systems of innovation approach. Applying these insights to the management of an individual firm, it could be concluded that the purchasing 
function can play a prominent role in a firm's drive for innovation by selecting the appropriate partners and supporting their integration.

Looking at the practical applicability of this approach, Rutten (2000) reports on a project that tried to reflect all the above. The development work for a new product was largely delegated to networks of suppliers. Even though the overall project was considered a success, there had been serious shortcomings: regularly, the engineering capacity of the selected suppliers had been overestimated, resulting in the need for substantial supplier development. Many of the suppliers had to learn how to engineer. This case study evidence underscores that the practical application of the network of innovations approach requires a substantial body of new know-how, beginning with the selection of the innovative supplier. The subsequent part of this paper therefore analyses which contributions research has been able to provide so far in the task of identifying innovative suppliers or such, who can become innovative in a buyer-supplier relation or in a network.

\section{The contribution of prior research: New product development, early supplier involvement and supplier selection}

It is hard to identify a large stream of research explicitly trying to answer the question of the characteristics of innovative suppliers, with notable exceptions (e.g. Cabral, Traill 1999; Håkansson, Eriksson 1993; Monnier 2005). However, three research streams immediately come into mind that could at least provide indirect input: research on purchasing involvement in NPD, early supplier involvement and the literature on supplier selection.

A few studies on NPD have tried to clarify under which conditions the purchasing department gets involved in new product development (e.g. Atuahene-Gima 1995; Burt, Soukup 1985; McGinnis, Vallopra 1999; Nijssen et al. 2002; Wynstra et al. 2003). The identification of innovative suppliers, however, is not explicitly analysed in these investigations. The important contribution of this line of research is to underscore the relevance of purchasing involvement in product development. Good internal co-operation is required for external co-operation, i.e. early involvement of purchasers is associated with early inclusion of suppliers (Hillebrand, Biemans 2004). Without suppliers being involved, their possible contribution to innovation is considerably limited by nature.

A similar picture arises in the research concerning early supplier involvement in the development process. Supplier integration often has been analysed without focussing on purchasing's role in this process (e.g. Bozdogan et al. 1998; Clark 1989; Eisenhardt, Tabrizi 1995; Gemünden et al. 1996; Kessler et al. 2000; Ragatz et al. 2001). As a consequence, the focus is more managing an existing constellation, rather than preparing the ground by selecting the right partners. A notable exception in this line of research is the work of Handfield et al. (1999) who explicitly ask for the criteria used to select innovative suppliers. Apart from demonstrating the benefits of early supplier inclusion, the contribution of the research into supplier involvement is more of an indirect nature: for example, some studies highlight the importance of frequent face-to-face communication. This finding means that suppliers with whom it is easier to communicate on a daily basis show a higher probability of contributing to the buyer's innovativeness than those from remote locations. This finding can serve as an indication that suppliers located closer to the buyer can be integrated more effectively into the process of innovation and are thus more likely to contribute to the innovativeness of a firm.

Finally, having a look at the contribution the purchasing discipline itself has delivered so far, again mostly indirect input is found. In a synopsis of 75 papers, Weber et al. (1991) conclude that since the early works on supplier selection criteria in the 1960ies, little has changed, except for the geographical aspect being more emphasised due to just-in-time techniques. The focus uses to be on price, product quality and delivery reliability. Based on a synopsis of 85 mostly German sources - identifying similar criteria as Weber et al. - Koppelmann (2000) concludes that supplier evaluation and selection should be differentiated according to the type of supplier. Selecting suppliers with a requirement for innovation has to follow different criteria than the selection of such suppliers whose product is only differentiated by its costs. Asking firms on their evaluation practices, Muschinski (1998) found that about halve of them did follow the advice of different selection sets for different suppliers. However, 
even in the sets for suppliers of complex production materials only $17 \%$ of the firms did use the criterion "potential for development", which could be associated with power of innovation of a supplier. Similarly, Choi and Hartley (1996) find the criterion "incremental improvement of the supplier" - a possible indicator for process innovations - only to range in the last quintile of importance. These early findings somewhat contrast with a recent survey evidencing that the suppliers' power of innovation has gained increasing attention as an element of supplier selection, at least with the group of leading firms (Goffre et al. 2005). Business starts to recognise the value of innovation-suppliers.

In sum, it seems fair to conclude that neither research nor practice have so far offered many tools helping to identify innovative suppliers. As a consequence, one may get the impression that choosing suppliers which contribute to the process of innovation is largely left to intuition or good luck, but is no result of systematic analysis and planning. While this attitude may have been acceptable in a time were partners external to the firm did not play a significant role in the process of innovation, a professionalisation of the supplier selection clearly becomes a necessity today. It also becomes clear that - in the absence of an integral theory of supplier innovativeness - propositions on the identification of innovative suppliers have to be derived from a variety of sources.

Proposing a first set of criteria to discerp innovative and more conservative suppliers is the objective of the last part of this paper. It follows a logic borrowed from strategic analysis, which commonly is divided into an internal and an external view. Understanding a supplier can be interpreted as a short strategic analysis of that firm. Thus, transferring the logic of strategic analysis to supplier selection, the internal analysis would focus on the individual characteristics of a supplier (P1 - P4 below). The firm is linked to its environment by a variety of connections. The relationship between buyer and seller is the one of interest here. Besides, the relationship issue tends to be stressed in the literature on collaborative innovation. It should therefore get special attention (P5 - P8). The external analysis would, finally, consider the particular environment of the supplier. Findings from industrial economy research are rewarding: the characteristics of the supplier's industry further influence its likelihood to be innovative (P9 - P10).

\section{Characteristics of innovative suppliers}

As a part of the literature on supplier selection, various supplier typologies have emerged. They facilitate the job of the purchaser by offering a form of classification. A particularly interesting typology for the purpose here at hand has been developed by measuring innovative capabilities of suppliers and then identifying types of suppliers by clustering the responses (Petroni, Panciroli 2002). The "Atype" suppliers are the highly innovative ones. They usually provide complete products with high technology content, offered in the context of full-blown partnerings. The least innovative ones are the "C-type" suppliers who are characterised by being largely de-specialised, operating in a number of different industries. The argument that supplier specialisation tends to be associated with innovation is also supported by another typology that identified the "technology specialist" as a business model operating on the basis of being highly innovative (Kaufman et al. 2000). An enquiry in the automotive sector, differentiating between subsystem, first-tier and low-tier suppliers, also found that the latter show much less of an industry specialisation - and are only one third as innovative, measured in terms of patents held (Liker et al. 1996). Therefore, the following proposition can be derived:

P1: Specialised firms are the more innovative ones, rather than the generic contractors supplying several industries.

Another point of importance is what Cohen and Levinthal (1990) call the "absorptive capacity" of a firm. It has been shown that firms tend to profit from co-operation in terms of innovations only if they do have a certain level of specific and similar know-how in-house (Cassiman, Veugelers 2002; Prabhu et al. 2005). Transferred to suppliers this means that they need to have a certain level of know-how in order to become innovative contributors. Likewise, the buyer's trust in the supplier's competence is an important element influencing the innovative outcome (Roy et al. 2003; Sako 1992). Suppliers' design capabilities, their process and product know-how and indicators for that, such as certificates obtained, are thus recommended to identify innovative suppliers (Ellram 1990; Koppelmann 2000). Confirming 
this view, suppliers' R\&D activities as well as technological innovations exceeding R\&D have been identified as determinants of a supplier's innovativeness (Cabral, Traill 1999). This is reflected, in its extreme, by the supplier who in principle does the work asked for, only, and the supplier who is able to support collaborative development. Therefore, the following proposition seems straightforward:

\section{P2: Firms with high internal development capability are likely to be the innovative ones.}

In their analysis of innovative suppliers in the food industry, Cabral and Traill (1999) found that innovative suppliers tended to be engaged in several collaborative relationships and external alliances, not only with the buyer at hand. The supplier's previous experience with collaboration may serve as an indicator for its capacity to innovate (Koppelmann 2000). This observation becomes plausible if one interprets it as an indicator for a company culture open to collaboration. The partnering literature has also found, for example, that within the multitude of North-sea oil co-operations a very limited number of firms was responsible for the bulk of the collaborative ventures, apparently collaboration being a part of their company strategy and / or of their company culture (Green, Keogh 1998). Therefore, the following proposition can be derived:

\section{P3: Innovative suppliers are engaged in several collaborative ventures at the same time.}

Another source of input for the identification of innovative suppliers can be the lessons drawn from cooperative projects or such, where innovations resulted from. Håkansson gives a representative summary after analysing 172 buyer-seller relationships: "First, we found that the typical partner is near at hand, important in terms of volume, and well established as partner." (Håkansson 1989, p. 118). These three features tend to be verified in other studies, as well as in related research.

Concerning partners being "near at hand" typical results have been identifying $70 \%$ or $80 \%$ of regional or national relationships, international co-operation being more an exception (Åhman 2005; Håkansson 1989; Revilla Diez 2002). This comes as no surprise, considering that the same studies document that in innovative relationships there is a very frequent face-to-face communication by several people, meeting once a month or more often, for example for testing. For network-innovations it is typical that they develop during the problem solving situation at work, immediacy of exchange almost being a precondition (Gammage, Schiele 2000). In the extreme, co-location of buyer-seller personnel is often mentioned as success factor for supplier integration into innovation (McGinnis, Vallopra 1999; Murphy, Heberling 1996; Ragatz et al. 1997). Also periodic visits to the suppliers and a trusted exchange of information tend to correlate with product quality, which could be associated with product innovation (Tan et al. 1998). Direct exchange is apparently facilitated, if the collaborating firms are located in physical proximity to each other. These results are in line with the "geography of innovation."

Research in economic geography clearly shows that innovative activity is not distributed evenly across the country, but concentrated to a limited number of locations. One reason for this is that knowledge has been found to migrate so slowly that it has often lost its value, when leaving its region of origin. Innovation clearly favours regionally bound networks of innovators (Archibugi, Pianta 1992; Breschi, Lissoni 2001; Feldman 1999; Jaffe et al. 1993; Maurseth, Verspagen 1998). Another reason may be that international co-operations do incur additional costs, derived not only from logistics but also from cultural differences. The study by Roberts (2001) on the change in R\&D behaviour in the last decade also showed that even though there is a growing internationalisation in research, its increase is small compared to the increase in the use of external sources. Asking for innovative suppliers, the locational aspect plays a role. Therefore, the following proposition can be derived:

\section{P4: Innovative suppliers are located in geographical proximity to the buyer.}

The next characteristic identified by Håkansson was the mutual relevance of the partners. His suppliers tended to be responsible for more than $5 \%$ of the total purchasing volume of their clients. The volume can serve as an indicator for the alignment of strategic intentions, which has been found 
to be a highly relevant success factor (Axelsson 1987; Håkanson 1993; Håkansson, Eriksson 1993; Handfield et al. 2000; Kannan, Tan 2002; Tan et al. 1998). Also purchasing theory supports the thesis of mutual importance. The popular Kraljič-Matrix, for instance, basically leads to the recommendation that strategic partnerings (that could often result in innovative solutions) should only be established with a supplier providing a material important to the buyer and on which the buyer has a certain power of influence (Kraljič 1983). Therefore, the following proposition can be derived:

\section{P5: Innovative suppliers and buyers are important for each other.}

The third aspect of the introductory quotation from Håkansson refers to the age of collaborative relationships. Previous experience with the partner is often mentioned as a supplier selection criterion or a success factor in collaboration (Batenburg, Rutten 2003; Håkanson 1993; Handfield et al. 1999; McCutcheon et al. 1997; Ragatz et al. 1997; van Echtelt, Wynstra 2002). The analysis of existing relationships have revealed them to be clearly elder than 10 years in average (Åhman 2005; Felde 2004; Håkansson 1989; Liker et al. 1996), the age even showing a positive correlation with financial performance and improving innovative results (Felde 2004). The innovative core of a relationship seems to be embedded into a wider, multi-layer relationship between two or more companies, most of which has been growing over time. Therefore, the following proposition can be derived:

\section{P6: The innovative supplier has a long history of collaboration with the buyer.}

Another source of inputs for identifying innovative suppliers can be the literature on supplier development. Supplier development programmes have been found to lead to an increase in innovations, primarly including process, but also product innovations (Krause et al. 2000; Monczka et al. 2002; Tracey, Tan 2001; Watts, Hahn 1993). Therefore, the supplier's improvement efforts could be a criterion to select innovative suppliers (Koppelmann 2000). Supplier development can be subdivided into passive and active measures, with the latter showing the greatest effect on innovation. Passive supplier development would include e.g. supplier evaluation schemes, communicated to the supplier but with its commitment to self-improvement, only. Active supplier development includes sending resident engineers to the supplier's site, supporting a supplier's personnel development programme or running joint improvement projects (Large 2000). It is important to notice that supplier development should not only be initiated in the case of supplier failure. Poor performance of a supplier, in principle, is a market imperfection, for competition should have eliminated poorly performing suppliers (Krause et al. 2000). Active supplier development aims at creating a world-class supply base for the firm that provides it with competitive advantages towards it competitors (Leenders 1988). Given the importance of supplier development and its association with an increase in innovation, the following proposition can be derived:

\section{P7: Innovative suppliers take part in an active supplier development programme with the buyer.}

Now, what are the characteristics of suppliers successfully integrated into development programmes? Literature indicates, again, a certain minimum size, further stressing proposition P5. Another important pre-condition mentioned is that joint improvement programmes only work if there is a mutual acceptance, if the buyer sees a feeling of commitment by the supplier and if the inter-firm communication is functioning on a trusted level (Handfield et al. 2000; Krause, Ellram 1996; Krause 1999; Large 2000). This latter point leads to another feature usually considered to be of utmost importance, if innovations are to develop in co-operation between two or more partners: the relationship between them.

In his empirical analysis Large (2003) found evidence that an open and friendly purchaser-supplier relationship correlates with the success of supplier management. It is worth remarking that a good relationship did not correlate with the suppliers' price level. Chen et al. (2004) report that communication and long-term orientation with supplier leads to higher customer responsiveness and correlates to a firm's financial performance. This goes along with their finding that the most relevant measures in supplier evaluation are those on relationship quality. The commonly assumed trade-off between a good buyer-seller relationship and low prices cannot be confirmed. Instead, success in new 
product development projects and innovation correlates with the quality of relationship (Felde 2004; Hoegl, Wagner 2005). Engineers have been found to consider the supplier's co-operativenes to be about twice as important as its technical competence for assuring technical success of a development project (McCutcheon et al. 1997). An explanation for the significance of a trusted relationship is that in the process of innovation new value is created the scope of which is difficult to anticipate. Still, the partners need to have confidence that afterwards a fair distribution of gains will take place. Without that confidence, an open exchange of ideas may be hampered. But without such an exchange process it is more difficult to find new combinations, i.e. to innovate.

How do such trusted relationships develop? A synopsis of 17 papers on relationship quality indicates that informal and open communication, but also the length of relationship and specific i.e. ideosynchratic investments in the relationship lead to trust and commitment (Stölzle, Helm 2003). Similar characteristics are associated with successful partnering projects and with the performance of supply chains in general (Hsiao et al. 2002; Veludo et al. 2004). In order to describe relationships it has become popular to draw back on Sako's (1992) seminal work, contrasting the collaborative, "mutual obligational" relationship between Japanese firms and their supply base with the "armth's length" relationship found within British supply chains, more confrontative in nature. Based on the association of harmonic buyer-seller relationships and potential for innovation the following hypothesis can be derived:

P8: The buyer enjoys a mutually obligational relationship with innovative suppliers.

The focus of analysis, so far, was on the innovative supplier itself and its characteristics. Then, the relationship between buyer and seller added further criteria to distinguish between suppliers likely to be innovative and those not. Finally, research of industrial economic origin completes the picture by elaborating on the relevance of the industry structure for the generation of innovations (Gaffard 1990).

In industrial economics there has been a discussion concerning the amount of players in an industry and innovation. Here, a stream of research has emerged, arguing that situations of oligopoly tend to be more beneficial to innovation (Arvantis, Hollenstein 1998; Edquist et al. 2000; Faber 1981; Kraft 1989). One logic behind is that in oligopolistic markets the competition is based less on price but more on quality. Interestingly, in analysing supplier-buyer relationships, contrary to his expectations, Felde (2004) found a significant and positive relationship between dependence on the supplier and innovative output. Since dependence is a characteristic of an oligopoly this finding further stresses the following proposition:

P9: Suppliers from oligopolistic supply markets are more innovative then suppliers hosted in polypolistic industry structures.

One may argue that the industry structure is alike for all members of a particular industry and that therefore it cannot help to make a distinction between two competing suppliers. On the one hand, such an analysis makes sense in the case of a make or buy decision. In the analysis of suppliers it must always be an option to consider that none of the supplier is likely to be sufficiently innovative, so that in that case the technology at hand should better be developed in house. The above made distinction is of further interest, if the task is to compare suppliers originating from different countries with different industry structures.

The international element has further influence: if there was a substantial multinational presence in the supply industry, a negative effect on innovation of domestic firms has been identified (Veugelers, Houte 1990). In such an environment it would not be advisable to choose domestic suppliers, if suppliers' contribution to a firm's innovativeness is a prime objective. On the other hand, if the local supply industry has a strong international position with few foreign firms having been able to establish themselves on the domestic market, this can be an indication of its power of innovation. This goes along with Kaufman et al.'s (2000) identification, in their supplier typology, of "problem solving" (i.e. innovative) suppliers, that are relatively large, profitable - and export oriented. Also the clusterapproach supports the assumption that suppliers with a strong export orientation are the more 
innovative ones, in arguing that the best suppliers tend to concentrate in the industry centre and from there serve the remaining world market, as well (Porter 1990; Schiele 2003). Therefore, the following proposition can be derived:

P10: Suppliers with a strong export orientation are more innovative than those from a purely domestic industry.

\section{Conclusions and next steps: the value of an innovative supply base}

Based on the above discussion a picture of an innovative supplier matures. It is a specialised, technically competent, export-oriented firm, located in proximity to the buyer and taking part in its supplier development programme. An intensive and trusted relationship has evolved over a long period of time.

Buyers may want to become the "preferred customer" of such valuable suppliers, ensuring their prime commitment, which "...implies that the manufacturer has to present itself as a kind of supplier to its supplier..." (Wynstra et al. 2003, p. 74). However, analysing the identified characteristics of innovative suppliers, one striking feature comes into view: there may be a limited choice in establishing innovative relationships on a short notice. If a firm misses a competent supply base to which it is linked in long-term and trusted exchange relationships it may first have to take the time to create it, in order to enjoy innovative input from the suppliers. Creating a network of innovation-suppliers is a new direction for supplier development programmes. It also requires more a long term planning for the supply base. For that purpose, in analysing the supply base, a buyer may find it helpful to distinguish between an inner circle of "innovation-suppliers" and an outer circle of "cost-suppliers". Both should be addressed by different means, the selection of innovation-suppliers including the above distilled criteria in addition to the more common price and logistic evaluation criteria. Eventually, the findings also support the thesis derived from a resource based view on the firm that the proximate environment of a firm, including its network of innovative suppliers, can enhance - or limit - its competitiveness, thus being a valuable resource difficult to imitate (Duschek 2004; Dyer, Singh 1998; Götze, Mikus 2002; Steinle et al. 1998). These implications sum up to the need of purchasing to expand its scope of analysis in supplier selection. Identifying innovative suppliers or those that can become innovative by collaborating with the buyer is a new task for strategic sourcing.

Finally, lending empirical support to the picture of an innovative supplier deduced above would be a logical next step in research. Regarding methodological issues on future research design, this could either be done by case study research or via a broad quantitative verification. Case studies have been considered to be particularly suited for investigating business-to-business relationships and even to confirm theories (Johnston et al. 2000). However, to enhance the validity of the findings further, a combination of the above in the sense of a triangulation, checking quantitative against qualitative data and vice versa, could be even more rewarding (Punch 2005). One form of quantitative verification could be to ask managers to indicate the criteria they use for choosing innovative suppliers or to indicate in how far they agree with the above developed propositions. However, it is not sure if the results of such a questionnaire would validely identify the characteristics of innovative suppliers. Verma and Pullman (1998) have undertaken an experiment, asking purchasing managers to indicate their supplier selection criteria and than apply this to 16 experimental supplier selection situations. "The results indicate that although managers say that quality is the most important attribute for a supplier, they actually choose suppliers based largely on cost and delivery performance." (Verma, Pullman 1998, p. 739). So asking for selection criteria may give more a picture of the intentions of the answering person rather than reflecting the reality of choice. Therefore, it seems preferable to try to identify the characteristics of the most innovative suppliers that are already working for a firm. Such a design would also overcome one of the limitations of the main body of research in the field of supplier integration, namely the focus on single projects rather then a comprehensive view on suppliers (Wynstra et al. 2003). Moving away from a single project perspective would require the managers first to make up the mind on which are actually their most innovative suppliers and then analyse their characteristics, maybe even contrasting them with the typical un-innovative supplier. 
A validated understanding about which suppliers are contributing with innovations and which are unlikely to do so paves the way for a constructive discussion between purchasing and R\&D on supplier selection and ultimately offers a substantial contribution to a firm's competitive advantage: with a growing reliance on external partners for innovative solutions, privileged access to innovative suppliers stands at the core, being one of the characteristics distinguishing between successful and less successful firms.

\section{References}

Åhman , Sara (2005), "Towards Strategic Purchasing in a Supply Network," in Sourcing decision management, A. Ancarani and M. Raffa, ed. Napoli, Roma, 101-113.

Archibugi, Daniele and Pianta, Mario (1992), The Technological Specialisation of Advanced Countries. A Report to the EEC on International Science and Technology Activities. Dordrecht, Boston, London.

Arvantis, Spyros and Hollenstein, Heinz (1998), "Innovative Activity and Firm Characteristics - A Cluster Analysis with Firm-level Data of Swiss Manufacturing," 25th Annual Conference of the European Association for Research in Industrial Economics, Copenhagen.

Atuahene-Gima, Kwaku (1995), "Involving Organizational Buyers in New Product Development," Industrial Marketing Management, 24, 215-226.

Axelsson, Björn (1987), "Supplier Management and technological development," in Industrial technological development, H. Håkansson, ed. London [etc.], 128-176.

Batenburg, Ronald and Rutten, Roel (2003), "Managing innovation in regional supply networks: a Dutch case of 'knowledge industry clustering'," Supply Chain Management: An International Journal, 8 (3), 263-270.

Bozdogan, Kirkor, Deyst, John, Hoult, David and Lucas, Malee (1998), "Architectural innovation in product development through early supplier integration," R\&D Management, 28 (3), 163-173.

Breschi, Stefano and Lissoni, Francesco (2001), "Knowledge Spillovers and Local Innovation Systems: A Critical Survey," Industrial and Corporate Change, 10 (4), 975-1005.

Burt, D. N. and Soukup, W. R. (1985), "Purchasing's role in new product development," Harvard Business Review, 63 (September / October), 90-97.

Cabral, José Ednilson O. and Traill, W. Bruce (1999), "Determinants of a firm's likelihood to innovate and intensity of innovation in the Brazilian food industry," Journal on Chain and Network Science, 1 (1), 33-48.

Cassiman, Bruno and Veugelers, Reinhilde (2002), "Complementarity in the innovation strategy: Internal r\&d, external technology acquisition and cooperation," Centre for Economic Policy Research, Discussion Paper Series, No. 3284, Cambridge.

Chen, Injazz J., Paulraj, Antony and Lado, Augustine A. (2004), "Strategic purchasing, supply management, and firm performance," Journal of Operations Management, 22 (5), 505-523. 
Choi, Thomas Y. and Hartley, Janet L. (1996), "An exploration of supplier selection practices across the supply chain," Journal of Operations Management, 14 (4), 333-343.

Christensen, Jens Fröslev (1996), "Innovative assets and inter-asset linkages - a resource-based approach to innovation," Economics of innovation and new technology, 4, 193-209.

Clark, K. B. (1989), "Project scope and project performance: the effects of parts strategy and supplier involvement on product development," Management Science, 35 (10), 1247-1263.

Cohen, Wesley M. and Levinthal, Daniel A. (1990), "Absorptive Capacity: A New Perspective on Learning and Innovation," Administrative Science Quarterly, 35 (1), 128-152.

Croom, Simon R. (2001), "The dyadic capabilities concept: examining the processes of key supplier involvement in collaborative product development," European Journal of Purchasing \& Supply Management, 7 (1), 29-37.

Duschek, Stephan (2004), "Inter-Firm Resources and Sustained Competitive Advantage," Management Revue, 15 (1), 53-73.

Dyer, Jefrey H. and Singh, Harbir (1998), "The relational view: cooperative strategy and sources of interorgnizational competitive advantage," Academy of Management Review, 23 (4), 660-679.

Edquist, Charles (1997), "Systems of Innovation Approaches - Their Emergence and Characteristics," in Systems of Innovation. Technologies, Institutions and Organizations, C. Edquist, ed. London, Washington, 1-35.

----, Hommen, Leif and Tsipouri, Lena J. (2000), Public technology procurement and innovation. Boston, Mass. [etc.].

Eisenhardt, Kathleen M. and Tabrizi, Behnam N. (1995), "Accelerating Adaptive Processes: Product Innovation in the Global Computer Industry," Administrative Science Quarterly, 40 (3), 84-110.

Ellram, Lisa M. (1990), "The Supplier Selection Decision in Strategic Partnerships," Journal of Purchasing and Materials Management, 20 (4), 8-14.

Faber, Stephen (1981), "Buyer market structure and r\&d effort: A simultaneous equations model," The Review of Economics and Statistics, 63 (3), 336-345.

Felde, Jan (2004), Supplier collaboration: an empirical analysis of Swiss OEM-supplier relationships. Bamberg.

Feldman, Maryann P. (1999), "The new economics of innovation, spillovers and agglomeration: a review of empirical studies," Economy Innovation New Technology, 8, 5-25. 
Freeman, Chris and Soete, Luc (1997), The Economics of Industrial Innovation, 3. ed. London, Washington.

Gaffard, Jean-Luc (1990), Économie industrielle et de l'innovation. Paris.

Gammage, John and Schiele, Holger (2000), "Netzwerkinnovationen verändern das Business Design: Ein Fall aus der Ölindustrie (English version available with the authors)," in Vitalisierung. Das Management der neuen Lebendigkeit, C. Steinle, B. Eggers, H. Thiem and B. Vogel, ed. Frankfurt a. M., 122-141.

Gemünden, Hans Georg, Ritter, Thomas and Heydebreck, Peter (1996), "Network configuration and innovation success: An empirical analysis in German high-tech industries," International Journal of Research in Marketing, 13, 449-462.

Goffre, Jules, Plaizier, Wim and Schade, Jesper (2005), "Scaling new hights. What separates the leaders from the followers in procurement today? A major benchmarking study offers some answers," CPO Agenda, 1 (1), 54-58.

Green, Richard and Keogh, William (1998), "Collaboration in the UK Upstream Oil and Gas Industry. Five Years On," 5th International Conference on Multi-Organisational Partnerships and Co-operative Strategy, Oxford.

Götze, Uwe and Mikus, Barbara (2002), "Standorte als Ressourcen - Implikationen des 'Resource Based View' für die Standortplanungslehre," Zeitschrift für Planung, 13, 401-429.

Håkanson, Lars (1993), "Managing cooperative research and development: partner selection and contract design," R\&D Management, 23 (4), 273-285.

Håkansson, Håkan (1989), Corporate technological behaviour. Co-operation and networks. London, New York.

---- and Eriksson, Ann-Kristin (1993), "Getting Innovations Out of Supplier Networks," Journal of Business-to-Business Marketing, 1 (3), 3-34.

Handfield, Robert B., Krause, Daniel R., Scannell, Thomas V. and Monczka, Robert M. (2000), "Avoid the Pitfalls in Supplier Development," Sloan Management Review, 41 (2), 37-49.

---- Ragatz, Gary L., Petersen, Kenneth J. and Monczka, Robert M. (1999), "Involving Suppliers in New Product Development," California Management Review, 42 (1), 59-82.

Hillebrand, Bas and Biemans, Wim G. (2004), "Links between Internal and External Cooperation in Product Development: An Exploratory Study," Journal of Product Innovation Management, 21 (o.), 110-122.

Hoegl, Martin and Wagner, Stephan M. (2005), "Buyer-Supplier collaboration in product development projects," Journal of Management, 31 (4), forthcoming. 
Hsiao, Melody J., Purchase, Sharon and Rahman, Shams (2002), "The impact of buyer-supplier relationship and purchasing process on the supply chain performance: a conceptual framework," 18th IMP-conference, Perth.

Jaffe, Adam B., Trajtenberg, Manuel and Hederson, Rebecca (1993), "Geographic localization of knowledge spillovers as evidenced by patent citations," The Quarterly Journal of Economics, 58 (3), 577-598.

Johnston, Wesley J., Leach, Mark P. and Liu, Annie H. (2000), "Using case studes for theory testing in business-to-business research: The development of a more rigorous case study methodology," Advances in Business Marketing and Purchasing, 9, 215-241.

Kannan, Vijay R. and Tan, Keah Choon (2002), "Supplier Selection and Assessment: Their Impact on Business Performance," The Journal of Supply Chain Management, 38 (4), 11-21.

Kaufman, Allen, Wood, Craig H. and Theyel, Gregory (2000), "Collaboration and technology linkages: a strategic supplier typology," Strategic Management Journal, 21, 649-663.

Kessler, Eric H., Bierly, Paul E. and Gopalakrishnan, Shanti (2000), "Internal vs. external learning in new product development: effects on speed, costs and competitive advantage," R\&D Management, $30,213-223$

Koppelmann, Udo (2000), Beschaffungsmarketing, 3. ed. Berlin [etc.]

Kraft, Kornelius (1989), "Market structure, firm characteristics and innovative activity," The Journal of Industrial Economics, 37 (3), 329-336.

Kraljič, Peter (1983), "Purchasing must become supply management," Harvard Business Review, 61 (5), 109-117.

Krause, Daniel R. (1999), "The antecedents of buying firms' efforts to improve suppliers," Journal of Operations Management, 17, 205-224.

---- and Ellram, Lisa M. (1996), "Success factors in supplier development," International Journal of Physical Distribution \& Logistics, 29 (1), 39-52.

----, Scannell, Thomas V. and Calantone, Roger J. (2000), "A Structural Analysis of the Effectiveness of Buying Firms' Strategies to Improve Supplier Performance," Decision Sciences, 31 (1), 33-55.

Large, Rudolf (2000), Strategisches Beschaffungsmanagement. Eine praxisorientierte Einführung, 2., überarbeitete und erweitete Auflage Wiesbaden.

---- (2003), Interpersonelle Kommunikation und erfolgreiches Lieferantenmanagement. Wiesbaden.

Leenders, Michiel R. (1988), Reverse marketing: the new buyer-supplier relationship. New York [etc.]. 
Liker, Jeffrey K., Kamath, Rajan R., Wasti, S. Nazli and Nagamachi, Mitsuo (1996), "Supplier involvement in automotive component design: are there really large US Japan differences?" Reseach Policy, 25, 59-89.

Maurseth, Per Botolf and Verspagen, Bart (1998), "Knowledge Spillovers in Europe and its Consequences for Systems of Innovation," Merit Research Memorandum 2/98-024, Maastricht.

McCutcheon, David M., Grant, Rebecca A. and Hartley, Janet (1997), "Determinants of new product designers' satisfaction with suppliers' contributions," Journal of Engineering and Technology Management, 14, 273-290.

McGinnis, Michael and Vallopra, Rafeekh Mele (1999), "Purchasing and Supplier Involvement: Issues and Insights Regarding New Product Success," The Journal of Supply Chain Management, 35 (3), 415.

Monczka, Robert, Trent, Robert and Handfield, Robert (2002), Purchasing and Supply Chain Management, 2nd edition Mason / OH.

Monnier, Bernard (2005), "A new tool to evaluate suppliers' level of innovation," in Researches in purchasing and supply management. Proceedings of the 14th IPSERA Conference, R. Calvi and N. Merminod, ed. Archamps, 1147-1154.

Murphy, David J. and Heberling, Michael E. (1996), "A Framework for Purchasing and Integrated Product Teams," International Journal of Purchasing and Materials Management, 32 (3), 11-19.

Muschinski, Willi (1998), "Lieferantenbewertung in Deutschland," Beschaffung Aktuell, 29 (9), 46-52.

Nijssen, Ed J., Biemans, Wim G. and de Kort, Joop F. (2002), "Involving purchasing in new product development," R\&D Management, 32 (4), 281-289.

Petroni, Alberto and Panciroli, Barbara (2002), "Innovation as a determinant of suppliers' roles and performances: an empirical study in the food machinery industry," European Journal of Purchasing \& Supply Management, 8, 135-149.

Porter, Michael E. (1990), The Competitive Advantage of Nations. Houndmills, London.

Prabhu, Jaideep C., Chandy, Rajesh K. and Ellis, Mark E. (2005), "The Impact of Acquisitions on Innovation: Poison Pill, Placebo or Tonic?" Journal of Marketing, 69 (1), 114-130.

Punch, Keith F (2005), Introduction to social research. Quantitative and qualitative approaches. Second edition, London, Thousend Oaks, New Dehli.

Ragatz, Gary L., Handfield, R. B. and Scannell, T. V. (1997), "Success Factors Integrating Supplier Into New Product Development," The Journal of Product Innovation Management, 14 (3), 190-203. 
Ragatz, Gary L., Handfield, Robert B. and Petersen, Kenneth J. (2001), "Benefits associated with supplier integration into new product development under conditions of technology uncertainty," Journal of Business Research, 55, 389-400.

Revilla Diez, Javier (2002), Betrieblicher Innovationserfolg und räumliche Nähe. Münster [etc.].

Roberts, Edward B. (2001), "Benchmarking Global Strategic Management of Technology. Survey of the word's largest $r \& d$ performers reveals, among other trends, a greater reliance upon external sources of technology," Research Technology Management, 44 (March-April), 25-36.

Roy, Subroto, Sivakumar, K. and Wilkinson, Ian (2003), "Innovation Generation in Supply Chain Relationships: A Conceptual Model and Research Propositions," Journal of the Academy of Marketing Science, 20 (10), 1-19.

Rutten, Roel P. J. H. (2000), "Innovation in Regional Supplier Networks: the Case of KIC," in Knowledge, Innovation and Economic Growth: the Theory and Practice of Learning Regions, F. Boekema, K. Morgan, S. Bakkers and R. Rutten, ed. Cheltenham, 217-244.

Sako, Mari (1992), Prices, quality and trust. Inter-firm relations in Britain and Japan. Cambridge.

Schiele, Holger (2003), Der Standort-Faktor. Wie Unternehmen durch regionale Cluster ihre Produktivität und Innovationskraft steigern. Weinheim.

Steinle, Claus, Eickhoff, Martin and Schiele, Holger (1998), "Zur Perspektivenerweiterung des Strategischen Management: Der 'innovative Cluster' als Wertschöpfungssystem und die Entwicklung von Kernkompetenzen," Zeitschrift für Planung, 9 (4), 367-390.

Stölzle, Wolfgang and Helm, Roland (2003), "Der Einfluss elektronischer Märkte auf die Beziehungsqualität - Theoretische Grundlagen und empirische Ergebnisse," in Integrated Supply Management. Einkauf und Beschaffung: Effizienz steigern, Kosten senken, R. Bogaschewsky, ed. Köln, 285-322.

Tan, Keah Choon, Kannan, Vijay R. and Handfield, Robert B. (1998), "Supply Chain Management: Supplier Performance and Firm Performance," International Journal of Purchasing and Materials, 34 (3), 2-9.

Tracey, Michael and Tan, Chong Leng (2001), "Empirical analysis of supplier selection and involvement, customer satisfaction, and firm performance," Supply Chain Management: An International Journal, 6 (4), 174-188.

van Echtelt, Ferrie and Wynstra, Finn (2002), "Managing Supplier Integration into Product Development: A Literature Review and Conceptual Model," ECIS Eindhoven Centre for Innovation Studies Working Paper 02.03, Eindhoven.

Veludo, Maria de Ludes, Macbeth, Douglas K. and Purchase, Sharon (2004), "Partnering and relationships within an international network context," International Marketing Review, 21 (2), 142-157. 
Verma, Rohit and Pullman, Madeleine E. (1998), "An Analysis of Supplier Selection Process," Omega, 26 (6), 739-750.

Veugelers, Reinhilde and Houte, Vanden (1990), "Domestic r\&d in the presence of multinational enterprises," International Journal of Industrial Organization, 8, 1-15.

Watts, Charles A. and Hahn, Chan K. (1993), "Supplier Development Programs: An Empirical Analysis," International Journal of Purchasing and Materials, 29 (1), 11-17.

Weber, Charles A., Current, John R. and Benton, W.C. (1991), "Vendor selection criteria and methods," European Journal of Operations Research, 50 (1), 2-18.

Wind, Jerry and Mahajan, Vijay (1997), "Issues and Opportunities in New Product Development: An Introduction to the Special Issue," Journal of Marketing Research, 34 (February), 1-12.

Wynstra, Finn, Weggeman, Mathieu and van Weele, Arjan (2003), "Exploring purchasing integration in product development," Industrial Marketing Management, 32, 69-83. 